\title{
Functional capacity, independence and home affordances of premature children attending daycare centers
}

\author{
Capacidade funcional, independência e estimulação \\ domiciliar de prematuros frequentadores de creches
}

\author{
Marcela Tamiasso Vieira ${ }^{[a, b]}$, Joselici da Silva ${ }^{[a, c]}$, Jaqueline da Silva Frônio ${ }^{[a]^{*}}$ \\ [a] Universidade Federal de Juiz de Fora (UFJF), Juiz de Fora, MG, Brazil \\ [b] Universidade Federal de Minas Gerais, (UFMG), Belo Horizonte, MG, Brazil \\ [c] Universidade de São Paulo (USP), Ribeirão Preto, SP, Brazil
}

\begin{abstract}
Introduction: Child development is the result of the interaction between biological and environmental factors. Objective: The aim of this study is to evaluate and compare the Functional Capacity, Independence and Home Affordances Level of Stimulation of premature children between 18 and 42 months, attending or not daycare centers. Methods: Cross-sectional study with a convenience sample of 26 premature children between 18 and 42 months, paired and divided into two groups: attending (study group) and not attending daycare centers (control group). Data was collected from the questionnaires AHEMD-SR, PEDI and an identification questionnaire. Data analysis was performed by descriptive statistics, and Chi-square, Fisher, Mann-Whitney and Univariate Analysis tests, considering the level of significance of $\alpha=0.05$ and tendency of differentiation when $\alpha<010$. Results: There was a significant difference in the AHEMD-SR`s Variety of Stimulation ( $p=0.036)$, higher in the control group, and tendency in the Gross Motor Toys $(p=0.086)$, more available in the study group. In PEDI, there was significant difference in Self-care $(p=0.045)$ and tendency of differentiation in Mobility (0.068), both of the Caregiver Assistance part (greater to the study). The sample showed low stimulation opportunities regarding Fine and Gross Motor Toys and high percentages of delay in Functional Skills (Mobility) and Independence (Self Care and Mobility), especially in the control group. Conclusion: Daycare centers seem to positively affect the Functional Capacity and Independence in premature children between 18 and 42 months.
\end{abstract}

Keywords: Child Development. Premature. Environment. Child Day Care Centers.

\footnotetext{
MTV: Master Student, e-mail: marcelatamiasso@gmail.com JS: MS, e-mail: joselici@yahoo.com.br

JSF: PhD, e-mail: jaqueline.fronio@ufjf.edu.br
} 


\section{Resumo}

Introdução: O desenvolvimento infantil é resultado da interação de fatores biológicos e ambientais. Objetivo: Verificar e comparar a Capacidade Funcional, a Independência e a Estimulação Presente no Ambiente Domiciliar de prematuros entre 18 e 42 meses, frequentadores e não frequentadores de creche. Métodos: Estudo transversal com amostra de conveniência de 26 prematuros entre 18 e 42 meses, pareados e divididos em frequentadores e não frequentadores de creche. Os dados foram coletados a partir do AHEMD-SR, do PEDI e de um questionário de identificação. A análise foi realizada por meio de estatística descritiva e testes Qui-quadrado, Fisher, Mann-Whitney e Análise Univariada, com nível de significância de $\alpha=0,05$ e tendência de diferenciação $\alpha<0,1$. Resultados: No AHEMD-SR, houve diferença significativa na Variedade de Estimulação ( $p=$ 0,036), maior para não frequentadores de creche, e tendência nos Materiais de Motricidade Grossa $(p=0,086)$, mais disponível para os frequentadores. No PEDI, na Assistência do Cuidador houve diferença significativa no Autocuidado ( $p=0,045)$ e tendência de diferenciação na Mobilidade (0,068), melhor entre os frequentadores de creche. A amostra apresentou baixas oportunidades de estimulação no domicílio em relação a Materiais para Motricidade Fina e Grossa e altos percentuais de atraso nas Habilidades Funcionais (Mobilidade) e na Independência (Autocuidado e Mobilidade), principalmente nos que não frequentavam creche. Conclusão: $A$ creche parece interferir positivamente na Capacidade Funcional e na Independência de nascidos prematuros entre 18 e 42 meses de idade.

Palavras-chave: Desenvolvimento Infantil. Prematuro. Meio Ambiente. Creches.

\section{Introduction}

The scientific and technological progress of the last two decades have allowed innovations in obstetric and neonatal care favoring the realization of interventions (1) which contributed to a significant increase in the survival of premature infants $(1,2)$, being prematurity a main risk factor for changes in the child development in different stages of their lives $(3,4)$.

Child development suffers continuous influence of intrinsic and extrinsic factors (risk or protective), which can vary from one person to another $(1,5)$. The intrinsic factors are inherent to the person such as low birth weight and prematurity $(1,2,3,5)$. The extrinsic factors are external elements that act on the child since the conception and include the stimuli and opportunities generated by the environment in which the child lives such as the level of education $(5,6,7)$ and socioeconomic status of the parents $(6-8)$.

Children show single differences in development that cannot be explained only by genetic characteristics and maturational pace. One possible explanation for this phenomenon are the environmental factors, which have assumed increasing prominence (9).

According to Mancini et al. (7), the high socioeconomic status of families is associated to favorable conditions to the child development such as increased parental education, increased access to information and higher purchasing power. The results of this study suggest that such sociocultural context could minimize or even neutralize any losses in motor performance resulting from prematurity compensating the effects of biological risk (7).

Premature children or with low birth weight show lower performance in the functional capacity and independence as compared to the children without these characteristics, but the environmental and socioeconomic conditions appear to have significant effect on the outcomes found $(10,11)$, highlighting the low education level of the mother $(11,12)$ and low socioeconomic status $(8,11,12)$.

According to Rossetti-Ferreira et al. (13), an important feature related to the sociocultural context is the higher attendance of children in daycare centers or preschool, which is due to socioeconomic transformations and the inclusion of women in the labor market. Daycare centers must be a place to fulfill the child's needs for nourishment, hygiene and stimulation, capable of promoting proper growth and development for children under six years old (14). According to Schoeps (15), daycare can allow, more effectively, the realization of collective educational interventions and health prevention, as they have a definite and stable population facilitating the access for the families aiming changes in habits and care. Therefore, daycare is another important environment 
that can influence child development and for this reason deserves special attention (16).

There is evidence that, in adverse conditions, the child development can be negatively influenced by daycare centers (17). The training of the professionals working in daycare centers (18) and the lack of knowledge about techniques to stimulate child development is related to the quality of the childcare (19). The high number of children in a restricted environment (20) and a greater number of infants being cared by a single caregiver can also be considered adverse conditions since less individual attention is given to each children resulting in less stimulation for acquiring new abilities (18 - 20). Added to this, the use of toys unsuitable for the age group or even the poor variation and availability of these toys can affect the motor repertoire (21).

Thus, it is observed that some studies indicate positive effects $(15,16)$ while others studies indicate negative effects of daycare centers (18 - 21) in child development, but the research on the subject remain scarce and little is known about its real effect of functional capacity, independence and home affordances of premature children. Also, there has not been found a study that could relate these aspects to the children attending and not attending daycare. Therefore, the aim of this study is to verify and compare the Functional Capacity, the level of Independence and the Stimulation present in the Home Environment of premature children between 18 and 42 months who attend and not attend daycare centers.

\section{Methods}

Study design and sample

A cross-sectional observational study was conducted analyzing a sample of premature infants born between 18 and 42 months, attending and not attending daycare (respectively, the study group and control group). These two groups were matched according to age, level of prematurity, socioeconomic status, gender and level of maternal education. For this study, all members registered in two follow-up services of Juiz de Fora, Minas Gerais, Brazil, who had born prematurely and were aged between 18 and 42 months during the data collection period (between August 2012 and July 2013) were considered potential participants for the study. Children with moderate to severe cerebral palsy (GMFCS III, IV or V) (22) or genetic syndromes and malformations were excluded from this study since that some aspects normally considered as stimuli or opportunities may represent barriers or limitations for children with a higher level of physical or intellectual impairment.

\section{Instruments and procedures}

The evaluations were carried through the Home Environment for Motor Development - Self Report (AHEMD-SR), $(23,24)$, the Pediatric Evaluation of Disability Inventory (PEDI) (25) and a survey consisting of questions about the children and their parents, and the questionnaire of the Brazilian Association of Research Companies (ABEP) (26).

The AHEMD-SR is a valid and reliable instrument consisting of a total of 67 questions that assesses how the home environment is promoting opportunities for infants between 18 and 42 months $(23,24)$. Its first part is related to the characterization of the children and their family, and the rest of the test is subdivided into five subscales: Outside Space, Inside Space, Variety of Stimulation, Gross Motor Toys and Fine Motor Toys (9).

The PEDI was standardized, validated and adapted to the Brazilian reality and consists of a questionnaire applied through an interview with the caregiver and records detailed description of Functional Performance and Independence in daily activities of children aged between six months to seven and a half years (25), and is divided in three parts. The first part (I) measures the repertoire of Functional Skills in the self-care, mobility and social function dimensions; the second part (II) refers to the level of care that the caregiver offers to the child in the implementation of these activities; and the third part (III) assesses the frequency of adjustments in the environment used by the child in the same functional activities (25). The third part of PEDI was not applied, as it was not the main focus of the study.

The instruments were applied by three academics of the Physical Therapy School, Federal University of Juiz de Fora (UFJF), and a physical therapist supervisor. The team received prior training before starting the data collection reaching over $90 \%$ intra and inter-examiner reliability in parts I and II of the PEDI.

This study is part of a larger research entitled "Opportunities of Stimulation at Home and Functional Capacity of Infants and Preschool children with or without history of risk factors for changes in Motor Development" and sought to collect data for all 379 infants enrolled in the follow-up services previously cited. After repeated attempts to contact all of the children and schedule for data collection, it was possible 
to evaluate only 112 children. Among these children, 20 met the criteria for inclusion and exclusion of the study group (attending daycare) and 55 met the criteria for the control group (not attend daycare centers). Considering the pairing criteria used in this study (age, level of prematurity, socioeconomic status, gender and level of maternal education), it was possible to pair 13 participants of the study group among the 55 potential participants of the control group. Thus, the final study sample consisted of a total of 26 infants and preschool children, being 13 participants of the study group (premature infants between 18 and 42 months old attending daycare centers) and 13 in the control group (premature infants between 18 and 42 months not attending daycare centers).

\section{Statistical Analysis}

Data from each participant was stored using the SPSS version 15.0 software. Because the distribution of the AHEMD-SR scores focused more on some classifications, the results were re-categorized in "very low and low" and "high and very high". In addition to the descriptive analysis of the characteristics of the participants in each group, inferential analysis were made of the findings of the instruments used in data collection.

Categorical variables were analyzed using the Chi-square or Fisher test (whenever the number of participants was below five in more than two subgroups in the classifications according to the assessments of the scales used). Continuous variables were tested for normality hypothesis and, as some did not include the criteria, it was used nonparametric test for statistical analysis (Mann-Whitney).

As statistical analysis might be considered an aspect that may interfere with the study outcome, it was established that the presence or absence of any pathology or deficit (Clinical Diagnostic), which was prior knowledge of parents and caregivers, would act as moderator variable according to information obtained by the professionals who accompanied the participant. The Univariate Analysis Test was then used to evaluate the interaction of the moderator variable (Clinical Diagnostic) on the independent variable (attending or not daycare) with the dependent variables (Stimuli at Home, Functional Capacity and Independence). The level of significance for the statistical tests was $\alpha=0.05$, and was considered as a tendency of differentiation when $\alpha<0.10$.

\section{Ethical aspects}

As previously stated, this study is part of a larger research, which was submitted and approved by the Research Ethics Committee (CEP) with Human Beings of UFJF under Reportno151.287/2012, to cover the items listed in Resolution 196/96. It was presented to the parents and/orthose responsible for the participants an informed consent form (ICF) that was signed after carefully being read, understood and agreed so the participant could be included in the study.

\section{Results}

Among the participants of the study, there was a predominance of females (61.5\% in each group), with an average gestational and approximate chronological age of 34 weeks and 31 months, respectively, in both groups. Regarding the socioeconomic status (ABEP classification), most of the sample was concentrated in the social classes $\mathrm{C} 1$ and $\mathrm{C} 2$ (respectively $38.5 \%$ and $30.8 \%$ for the study group, and $46.2 \%$ and $30.8 \%$ for the control group), being the most common income below $\mathrm{R} \$ 1.500 .00$ (61.6\% in the study group and $69.3 \%$ of control group). There was a higher concentration of infants with low birth weight $(\geq 1,500 \mathrm{~g}$ and $<2,500 \mathrm{~g})$ representing $84.6 \%$ of the study group and $51.5 \%$ of control group and there were more participants with Clinical Diagnostic report in the study group (46.2\%, while in the control group this percentage was $15.4 \%$ ). In both groups the mothers were on average 32.08 years old and had similar education where the majority of them studied over 8 years $(61.5 \%)$ and none of them was illiterate.

The analysis of the AHEMD-SR (Tables 1 and 2) showed an "average level" of home affordances in more than two-thirds of the participants in both groups. There was a significant association in comparison of the dimension Variety when analyzed as a continuous variable $(\mathrm{p}=0.036)$ and a tendency to association when categorized ( $\mathrm{p}=0.063)$, indicating a greater variety of opportunities in the homes of children in the control group. It was also found a significant tendency in association in the dimension Gross Motor Toys as a continuous variable ( $p=0.086)$; indicating that there is higher availability of these in the home environment of the study group (children attending daycare). Regarding the other dimensions, 
there were slight differences with no predominance of better or worse performance, indicating no significant distinctions or tendencies between the groups. Noteworthy that more than two thirds of the participants in both groups received the rating "very low and low" in the dimensions Fine and Gross Motor Toys of the AHEMD-SR.

Table 1 - Classification and Comparison of AHEMD-SR Categorical Variables between Premature Children Attending daycare (Study Group) and Not attending daycare (Control Group)

\begin{tabular}{|c|c|c|c|}
\hline Group & $\begin{array}{l}\text { Attending } \\
\text { daycare }\end{array}$ & $\begin{array}{l}\text { Not attending } \\
\text { daycare }\end{array}$ & \\
\hline Variables & $f(\%)$ & $f(\%)$ & p-value* \\
\hline \multicolumn{4}{|l|}{ AHEMD-SR Total } \\
\hline Low & $2(15.4 \%)$ & $2(15.4 \%)$ & \\
\hline Medium & $10(76.9 \%)$ & 11 (84.6\%) & $0.592^{*}$ \\
\hline High & $1(7.7 \%)$ & $0(0 \%)$ & \\
\hline \multicolumn{4}{|l|}{ Outside Space } \\
\hline Very low/low & $6(46.2 \%)$ & $4(30.8 \%)$ & $0.420 *$ \\
\hline High/very high & $7(53.8 \%)$ & $9(69.2 \%)$ & \\
\hline \multicolumn{4}{|l|}{ Inside Space } \\
\hline Very low/low & $2(15.4 \%)$ & $2(15.4 \%)$ & $0.703^{* \star}$ \\
\hline High/very high & $11(84.6 \%)$ & $11(84.6 \%)$ & \\
\hline \multicolumn{4}{|l|}{ Variety } \\
\hline Very low/low & $5(38.5 \%)$ & $1(7.7 \%)$ & $0.063^{*}$ \\
\hline High/very high & $8(61.5 \%)$ & $12(92.3 \%)$ & \\
\hline \multicolumn{4}{|l|}{ Fine motor skill } \\
\hline Very low/low & $11(84.6 \%)$ & $12(92.3 \%)$ & 0.500 ** \\
\hline High/very high & $2(15.4 \%)$ & $1(7.7 \%)$ & \\
\hline \multicolumn{4}{|l|}{ Gross motor skill } \\
\hline Very low/low & $12(92.3 \%)$ & $13(100 \%)$ & 0.500 ** \\
\hline High/very high & $1(7.7 \%)$ & $0(0 \%)$ & \\
\hline
\end{tabular}

Note: $\mathrm{f}=$ frequency; $\%=$ percentage; ${ }^{*}$ Chi-square $\left(\chi_{2}\right) ;{ }^{*}$ Fisher test.
Table 2 - AHEMD-SR analysis (total and dimensions) as continuous variables between Premature Children Attending daycare (Study Group) and Not attending daycare (Control Group)

\begin{tabular}{|c|c|c|c|c|c|}
\hline Variables & Min. & $\begin{array}{l}\text { Mean } \pm \\
\text { SD }\end{array}$ & Med. & Max. & p-value* \\
\hline \multicolumn{6}{|l|}{$\begin{array}{l}\text { AHEMD-SR } \\
\text { total }\end{array}$} \\
\hline $\begin{array}{l}\text { Attending } \\
\text { daycare }\end{array}$ & 8 & $\begin{array}{c}11.00 \pm \\
2.380\end{array}$ & 10.00 & 17 & 0.419 \\
\hline $\begin{array}{l}\text { Not attending } \\
\text { daycare }\end{array}$ & 9 & $\begin{array}{c}11.54 \pm \\
2.066\end{array}$ & 11.00 & 16 & \\
\hline \multicolumn{6}{|l|}{ Outside space } \\
\hline $\begin{array}{l}\text { Attending } \\
\text { daycare }\end{array}$ & 1 & $\begin{array}{c}2.54 \pm \\
0.776\end{array}$ & 3.00 & 4 & 0.513 \\
\hline $\begin{array}{l}\text { Not attending } \\
\text { daycare }\end{array}$ & 1 & $\begin{array}{c}3.62 \pm \\
0.768\end{array}$ & 4.00 & 4 & \\
\hline \multicolumn{6}{|l|}{ Inside space } \\
\hline $\begin{array}{l}\text { Attending } \\
\text { daycare }\end{array}$ & 1 & $\begin{array}{l}3.54 \pm \\
0.967\end{array}$ & 4.00 & 4 & 0.945 \\
\hline $\begin{array}{l}\text { Not attending } \\
\text { daycare }\end{array}$ & 2 & $\begin{array}{c}3.62 \pm \\
0.768\end{array}$ & 4.00 & 4 & \\
\hline \multicolumn{6}{|l|}{ Variety } \\
\hline $\begin{array}{l}\text { Attending } \\
\text { daycare }\end{array}$ & 1 & $\begin{array}{l}3.00 \pm \\
1.080\end{array}$ & 3.00 & 4 & 0.036 \\
\hline $\begin{array}{l}\text { Not attending } \\
\text { daycare }\end{array}$ & 2 & $\begin{array}{c}3.77 \pm \\
0.599\end{array}$ & 4.00 & 4 & \\
\hline \multicolumn{6}{|l|}{ Fine motor skill } \\
\hline $\begin{array}{l}\text { Attending } \\
\text { daycare }\end{array}$ & 1 & $\begin{array}{c}1.54 \pm \\
0.776\end{array}$ & 1.00 & 3 & 0.394 \\
\hline $\begin{array}{l}\text { Not attending } \\
\text { daycare }\end{array}$ & 1 & $\begin{array}{c}1.31 \pm \\
0.630\end{array}$ & 1.00 & 3 & \\
\hline \multicolumn{6}{|l|}{$\begin{array}{l}\text { Gross motor } \\
\text { skill }\end{array}$} \\
\hline $\begin{array}{l}\text { Attending } \\
\text { daycare }\end{array}$ & 1 & $\begin{array}{c}1.62 \pm \\
0.870\end{array}$ & 1.00 & 4 & 0.086 \\
\hline $\begin{array}{l}\text { Not attending } \\
\text { daycare }\end{array}$ & 1 & $\begin{array}{c}1.15 \pm \\
0.376\end{array}$ & 1.00 & 2 & \\
\hline
\end{tabular}

Note: Min = minimum; SD = standard deviation; Med = medium; Max. $=$ maximum; *Mann-Whitney.

When comparing the performance in normative scores of the areas of PEDI (Tables 3 and 4), the analysis of continuous variables showed a significant difference in the Self-care area $(p=0.045)$ and differentiation tendency in Mobility ( $p=0.068$ ), both part of the Caregiver 
assistance, with better performance in the study group. Although no significant discrepancies were found regarding the classification of the participants in the other areas and when it was considered the normative score in all parts of the PEDI, the study group also achieved better scores than the control group. Noteworthy is the high prevalence of the delay in the development in some areas, especially in the Mobility in the Caregiver Assistance (Part II), being present in more than half of participants in the control group.

Table 3 - Classification of normative standardized PEDI scores (delay, within typical limits, superior performance) between the children attending and not attending daycare

\begin{tabular}{|c|c|c|c|}
\hline Group & $\begin{array}{l}\text { Attending } \\
\text { daycare }\end{array}$ & $\begin{array}{l}\text { Not } \\
\text { attending } \\
\text { daycare }\end{array}$ & \\
\hline Variables & $f(\%)$ & $f(\%)$ & p-value* \\
\hline \multicolumn{4}{|c|}{$\begin{array}{l}\text { Part I: Functional Skills } \\
\text { Self-care }\end{array}$} \\
\hline Delay & $0(0.0)$ & $1(7.7)$ & 0.500 ** \\
\hline Within typical limits & $13(100.0)$ & $12(92.3)$ & \\
\hline \multicolumn{4}{|c|}{ Mobility } \\
\hline Delay & $1(7.7)$ & $4(30.8)$ & $0.161^{\star \star}$ \\
\hline Within typical limits & $12(92.3)$ & $9(69.2)$ & \\
\hline \multicolumn{4}{|c|}{ Social Function } \\
\hline Within typical limits & $12(92.3)$ & $13(100.0)$ & $0.500^{* *}$ \\
\hline Superior performance & $1(7.7)$ & $0(0.0)$ & \\
\hline \multicolumn{4}{|c|}{ Part II: Caregiver assistance } \\
\hline \multicolumn{4}{|c|}{ Self-care } \\
\hline Delay & $1(7.7)$ & $4(30.8)$ & 0.161 ** \\
\hline Within typical limits & $12(92.3)$ & $9(69.2)$ & \\
\hline \multicolumn{4}{|l|}{ Mobility } \\
\hline Delay & $4(30.8)$ & $7(53.8)$ & $0.349^{*}$ \\
\hline Within typical limits & $8(61.5)$ & $6(46.2)$ & \\
\hline Superior performance & $1(7.7)$ & $0(0.0)$ & \\
\hline \multicolumn{4}{|c|}{ Social Function } \\
\hline Delay & $1(7.7)$ & $1(7.7)$ & $0.760^{* *}$ \\
\hline Within typical limits & $12(92.3)$ & $12(92.3)$ & \\
\hline
\end{tabular}

Note: $f=$ frequency; $\%=$ percentage; ${ }^{\star}$ Chi-square $\left(\chi_{2}\right) ;{ }^{*}$ *Fisher test.
Table 4 - Analysis of PEDI's dimensions as Continuous Variables between Premature Children Attending daycare (Study Group) and Not attending daycare (Control Group)

\begin{tabular}{|c|c|c|c|c|c|}
\hline Variables & Min. & Mean \pm SD & Med. & Max. & p-value* \\
\hline \multicolumn{6}{|c|}{ Part I: Functional Skills } \\
\hline Self-care & & & & & \\
\hline $\begin{array}{l}\text { Attending } \\
\text { daycare }\end{array}$ & 30.60 & $47.90 \pm 8.94$ & 49.40 & 61.20 & 0.457 \\
\hline $\begin{array}{c}\text { Not } \\
\text { attending } \\
\text { daycare }\end{array}$ & 26.30 & $44.55 \pm 11.131$ & 43.70 & 62.10 & \\
\hline \multicolumn{6}{|l|}{ Mobility } \\
\hline $\begin{array}{l}\text { Attending } \\
\text { daycare }\end{array}$ & 9.90 & $42.31 \pm 12.753$ & 44.80 & 58.40 & 0.200 \\
\hline $\begin{array}{c}\text { Not } \\
\text { attending } \\
\text { daycare }\end{array}$ & 9.90 & $36.81 \pm 11.901$ & 39.40 & 50.20 & \\
\hline \multicolumn{6}{|l|}{$\begin{array}{l}\text { Social } \\
\text { Function }\end{array}$} \\
\hline $\begin{array}{c}\text { Attending } \\
\text { daycare }\end{array}$ & 38.60 & $54.05 \pm 10.159$ & 53.30 & 79.30 & 0.182 \\
\hline $\begin{array}{c}\text { Not } \\
\text { attending } \\
\text { daycare }\end{array}$ & 31.60 & $48.31 \pm 8.419$ & 46.50 & 64.70 & \\
\hline
\end{tabular}

Part II: Caregiver assistance

\begin{tabular}{|c|c|c|c|c|c|}
\hline \multicolumn{6}{|l|}{ Self-care } \\
\hline $\begin{array}{c}\text { Attending } \\
\text { daycare }\end{array}$ & 15.70 & $41.25 \pm 9.899$ & 45.50 & 53.40 & 0.045 \\
\hline $\begin{array}{c}\text { Not } \\
\text { attending } \\
\text { daycare }\end{array}$ & 9.90 & $33.14 \pm 13.963$ & 31.50 & 61.50 & \\
\hline \multicolumn{6}{|l|}{ Mobility } \\
\hline $\begin{array}{l}\text { Attending } \\
\text { daycare }\end{array}$ & 9.90 & $42.62 \pm 20.555$ & 45.90 & 85.10 & 0.068 \\
\hline $\begin{array}{c}\text { Not } \\
\text { attending } \\
\text { daycare }\end{array}$ & 9.90 & $27.84 \pm 17.635$ & 27.50 & 58.20 & \\
\hline \multicolumn{6}{|l|}{$\begin{array}{l}\text { Social } \\
\text { Function }\end{array}$} \\
\hline $\begin{array}{c}\text { Attending } \\
\text { daycare }\end{array}$ & 28.10 & $44.17 \pm 7.461$ & 43.80 & 60.70 & 0.136 \\
\hline $\begin{array}{c}\text { Not } \\
\text { attending } \\
\text { daycare }\end{array}$ & 18.70 & $39.22 \pm 9.690$ & 39.00 & 59.50 & \\
\hline
\end{tabular}

Note: Min. = minimum; SD = standard deviation; Med = medium; Max. $=$ maximum; *Mann-Whitney. 
The caregivers of the children of the sample reported the presence of the following "Clinical Diagnostic": in the study group there were two children with asthma and two children with bronchitis and sinusitis; and in the control group there were one child with asthma and one child with bronchopulmonary dysplasia and hydrocephalus grade I. In order to verify if the moderator variable
Clinical Diagnostic interfered in the findings, it was performed a Univariate Analysis (Table 3) that found no significant interference of this variable. Despite this, the best scores of the PEDI were found in the group that attended daycare, with more visible difference between those who did not showed any Clinical Diagnostic.

Table 5 - Interaction of the Variable Moderator Clinical Diagnostic with the Continuous Variables AHEMD-SR and PEDI between Premature Children Attending daycare (Study Group) and Not attending daycare (Control Group)

\begin{tabular}{|c|c|c|c|c|c|c|}
\hline CLINICAL DIAGNOSTIC & Yes & & No & & & \\
\hline GROUP & Attending daycare & $\begin{array}{l}\text { Not attending } \\
\text { daycare }\end{array}$ & Attending daycare & $\begin{array}{l}\text { Not attending } \\
\text { daycare }\end{array}$ & & \\
\hline VARIABLES & Mean $\pm S D$ & $M e a n \pm S D$ & Mean $\pm S D$ & $M e a n \pm S D$ & $\mathbf{F}$ & p-value* \\
\hline \multicolumn{7}{|l|}{ AHEMD-SR } \\
\hline Total & $10.00 \pm 1.897$ & $12.50 \pm 2.121$ & $11.86 \pm 2.545$ & $11.36 \pm 2.111$ & 2.067 & 0.165 \\
\hline Outside Space & $2.50 \pm 0.548$ & $3.50 \pm 0.707$ & $2.57 \pm 0.976$ & $2.55 \pm 1.128$ & 1.258 & 0.274 \\
\hline Inside Space & $3.33 \pm 1.211$ & $4.00 \pm 0.000$ & $3.71 \pm 0.756$ & $3.55 \pm 0.820$ & 0.975 & 0.334 \\
\hline Variety & $2.83 \pm 1.169$ & $4.00 \pm 0.000$ & $3.14 \pm 1.069$ & $3.73 \pm 0.647$ & 0.463 & 0.503 \\
\hline Fine Motor Skill & $1.50 \pm 0.548$ & $1.00 \pm 0.000$ & $1.57 \pm 0.976$ & $1.36 \pm 0.674$ & 0.177 & 0.678 \\
\hline Gross Motor Skill & $1.33 \pm 0.516$ & $1.00 \pm 0.000$ & $1.86 \pm 1.069$ & $1.18 \pm 0.405$ & 0.291 & 0.595 \\
\hline \multicolumn{7}{|l|}{ PEDI } \\
\hline FS Self-care & $\begin{array}{l}43.61 \pm 10.804 \\
10.804\end{array}$ & $\begin{array}{l}39.40 \pm 18.526 \\
18.526\end{array}$ & $\begin{array}{l}51.57 \pm 5.338 \\
5.338\end{array}$ & $\begin{array}{l}45.49 \pm 10.396 \\
10.396\end{array}$ & 0.039 & 0.845 \\
\hline FS Mobility & $\begin{array}{l}39.20 \pm 16.602 \\
16.602\end{array}$ & $\begin{array}{l}29.20 \pm 27.294 \\
27.294\end{array}$ & $\begin{array}{l}44.97 \pm 8.813 \\
8.813\end{array}$ & $38.19 \pm 9.044$ & 0.074 & 0.788 \\
\hline $\begin{array}{l}\text { FS Social } \\
\text { Function }\end{array}$ & $\begin{array}{l}48.43 \pm 6.345 \\
6.345\end{array}$ & $44.45 \pm 2.899$ & $\begin{array}{l}58.86 \pm 10.693 \\
10.693\end{array}$ & $49.00 \pm 8.983$ & 0.494 & 0.490 \\
\hline SC Self-care & $\begin{array}{l}40.30 \pm 13.255 \\
13.255\end{array}$ & $35.25 \pm 6.859$ & $\begin{array}{l}42.07 \pm 6.920 \\
6.920\end{array}$ & $\begin{array}{l}32.75 \pm 15.106 \\
15.106\end{array}$ & 0.127 & 0.725 \\
\hline SC Mobility & $\begin{array}{l}34.48 \pm 17.625 \\
17.625\end{array}$ & $\begin{array}{l}29.85 \pm 28.214 \\
28.214\end{array}$ & $\begin{array}{l}49.69 \pm 21.52 \\
21.52\end{array}$ & $\begin{array}{l}27.47 \pm 17.107 \\
17.107\end{array}$ & 0.928 & 0.346 \\
\hline $\begin{array}{l}\text { SC Social } \\
\text { Function }\end{array}$ & $\begin{array}{l}39.15 \pm 5.950 \\
5.950\end{array}$ & $38.90 \pm 2.970$ & $\begin{array}{l}48.47 \pm 5 ., 919 \\
5.919\end{array}$ & $\begin{array}{l}39.27 \pm 10.572 \\
10.572\end{array}$ & 1.293 & 0.268 \\
\hline
\end{tabular}

Note: SD = standard deviation; FS = functional skills; SC = self-care; *Univariate Analysis test.

\section{Discussion}

Child development is the result of the interaction of biological factors (such as prematurity) and environmental factors created by incentives and opportunities offered by the environment in which the child lives (3 - 8). Once the daycare is not only an option but also a necessity increasingly present in the family reality, the aim of this study was to evaluate and compare the effects that daycare might have in the Functional Capacity, the level of Independence and the Stimuli present in the homes of premature children born between 18 and 42 months.

It was believed that attending daycare could benefit premature infants. However, there was scarce and inconclusive data confirming this statement in literature. This lack of information made it difficult to structure the discussion of this study, which indirectly 
compared these benefits through studies that have already evaluated similar topics. These differences can even be related to the level of stimulation present in the home, which has not been previously measured between children who attend or not daycare centers.

Prematurity was the only biological risk factor emphasized in this study in order to homogenize the sample since it has relevant effect in child development and is directly correlated with other risk factors such as low birth weight $(27,28)$, the presence of associated diseases $(2,28)$, the length of hospital stay after birth $(27$, 28 ) and the need to stay on mechanical ventilation (28).

Regarding the total AHEMD-SR score, it was found more than two-thirds of "average rating" of the stimulation level present in the residences of both groups (at $76.9 \%$ and $84.6 \%$, respectively, study and control group). These findings confirm other studies with Brazilian populations (29) with and without biological risk factors $(30,31)$. Therefore, it seems that additional stimulation is not being offered to premature infants in their home environment.

This study found relevant aspects concerning the discrepancies between children attending and not attending daycare centers. Regarding the dimension Variety of the AHEMD-SR (encouragement to play, freedom of movement, stimulation and encouragement, daily activities) there was significant advantage for the group that did not attend daycare (control group). This outcome may be related to the fact that the participants of this group spent more time at home, which counteracts the Schobert's study (31) that found the classification "High" and "Very High" for the dimension of Variety of Stimuli in more than $95 \%$ of the children attending daycare. This difference may be associated to the fact that the author has improperly used the AHEMD version developed and standardized for other group age (18 to 42 months - AHEMD-SR) to evaluate infants between six and 18 months.

The study group (attending daycare) showed greater availability of Gross Motor Toys in the home environment (spring toys, multiple activity tables, musical toys, gross motor toys, locomotion materials, body exploration toys). One of the possible hypotheses for this conclusion is that parents' contacts with toys and games that children experience in the daycare environment, and/or the possible guidance received from the professionals involved with these care made the parents or guardians aware of the importance of these materials in the development of their children, a matter that would require further investigation in future studies.

Noteworthy, is the very low score found in both groups regarding the presence of materials that stimulate Gross and Fine Motor Skills (make-believe toys, interlocking toys, educational toys, games, construction materials) as the literature states that toys and games are the factors that most influence the motor development in the first years of life (30). These findings are similar to the ones of Silva \& Aguiar (29), Noble et al. (30), Schobert (31) and Pilatti et al. (32) according to which most of the sample was classified as "Very Low" and "Poor" in AHEMD-SR in these dimensions.

The low socioeconomic condition present in the sample (most of them with a lower income than $\mathrm{R} \$ 1.500 .00$, belonging to the classes $\mathrm{C} 1$ and C2 - according to the ABEP classification) may partially explain the low level of stimulation found in the dimensions Fine and Gross Motor Skill, as previous studies showed positive correlation between socioeconomic status and the quality and quantity of toys at home, since there is better chance of families with higher purchasing power to purchase toys for their children $(6,31)$. Lack of parental knowledge regarding which toys are best suited to stimulate the development of their children can lead to prioritizing other goods $(2$, 29) or purchasing unsuitable toys with little variation (6). This implicates the need for trained professionals to better guide parents as to the acquisition and use of toys, as was also suggested by Noble et al. (30).

In this study, as well as in Noble et al. (30), as the majority of the participants obtained average rating in the total AHEMD-SR score, it can be considered that the microsystem home cannot meet the needs of opportunities to promote the motor development of children, especially because they are children with biological risk factors. Based on the concept that child development is a reflection of the interaction of biological and environmental factors (3 - 8), it is important that these children interact actively in other microsystems (such as the daycare) that might compensate for possible deficit of opportunities at home (30).

As for the functional capacity and the level of independence, the group that attended daycare performed better in all areas of PEDI being these differences significant to the Caregiver Assistance in self-care and mobility. Thus, participants who did not attend daycare needed more help from parents or caregivers to perform tasks related to self-care (such 
as dressing, bathing and doing personal hygiene) and mobility (such as going up and down the stairs and get around indoors and outdoors) than those attending daycare. In a way, this result was expectedas the relation between caregiver and child in daycare centers is usually reduced, not allowing such individualized attention to infants and preschool children encouraging them to do some of these activities with little help.

Lemos etal. (10) found similar results indicating that children attending daycare or school show more selfcare skills than those who do not attend. This finding is more significant when considering the presence of a large number of participants with some kind of a Clinical Diagnostic in this group suggesting that daycare centers influence positively in the development of premature children contradicting the additional vulnerability conferred by the presence of some pathology (Clinical Diagnostic).

In this study, high percentages of delay were found in some areas: $30.8 \%$ in the group that did not attend daycare in Mobility of Part I of PEDI (Functional Skills); $30.8 \%$ in the group that did not attend daycare in the Self-Care (Part II); 30.8\% of children attending daycare and $53.8 \%$ of those who did not attend daycare in the Mobility dimension in the Caregiver Assistance section (Part II). These findings indicate that, regardless attending or not daycare, these premature children need special attention in order to acquire functional skills and independence. The findings related to the mobility dimension in both parts of the inventory corroborate the findings of Lemos et al. (10), which involved infants with different biological risk factors.

Some sample features may be related to results of PEDI, once some studies have correlated the low socioeconomic level with delay in development. Thus, poverty appears to narrow the opportunities for development as it may not only hinder the acquisition of suitable toys but is also usually associated to smaller homes with larger numbers of residents and parents with little time to dedicate to their children $(20,33)$.

Although not significant, when checking the effect of the moderator variable "Clinical Diagnostic" in the interaction of the independent variable (attending or not daycare) with the dependent variables (Stimuli present in the house, Functional Capacity and Independence) it was found some data that are worth mentioning. When there was a "Clinical Diagnostic", attending daycare led to better results in terms of Functional Capacity and Independence and the difference was most evident in the absence of "Clinical Diagnostic". These findings suggest that attending daycare seems to positively affect the Functional Capacity and Independence, even in the presence of "Clinical Diagnostic".

When analyzing simultaneously the results in AHEMD-SR and PEDI, it is observed that having the highest level of stimulation in the home environment in one group does not mean having the highest level of functional capacity and independence. Therefore, it is believed that many of the results of this sample are not explained primarily by stimuli present in the home environment.

Overall, it appears that the daycare is partially compensating for the lack of opportunities present at home regarding the functional capacity and independence of premature children born between 18 and 42 months, even in the presence of some "Clinical Diagnostic". Future studies would be important to identify which daycare features are compensating for the lack of home stimuli.

Despite these results, some limitations should be considered. The number of participants in each group was small, which might have hindered the perception of the statistical tests of behavior inherent in the profile of the studied children, but it was decided to maintain the sample homogeneity and minimize the effects of confusing variables through rigorous pairing groups. Due to the size of the sample it was not possible to verify whether there was interference of some variables in the findings (such as differences in the follow-up services, and daycare features such as type, length of stay and frequency), and it is recommended that this should be verified in future studies. It is also suggested conducting further studies with larger samples to confirm or refute the findings of this study.

\section{Conclusion}

From the results found in this study, it is clear that premature children suffer different effects of home affordances in functional capacity and independence when attending or not daycare centers.

Preterm children born between 18 and 42 months old, who do not attend daycare centers, show high percentage of delays in functional capacity in the mobility area and Independence regarding self-care and mobility affecting more than a half of the participants in the later area. As for the children who attend daycare there was a high percentage of delay in the independence and mobility areas. 
Children attending daycare centers show more gross motor toys available at their homes and greater independence in the self-care and mobility dimensions when compared to those children with same characteristics who do not attend daycare. The group that remains longer at home (those children not attending daycare) receives more variety of stimulation at home.

Thus, daycare seems to positively interfere in the functional capacity and in the independence of premature children born between 18 and 42 months old.

\section{Acknowledgments}

To the valuable contribution of Daniele Silva and Talita Aguiar and to the availability of the follow-up staffs and the parents of the participants of the study.

\section{References}

1. Fuchino Y, Naoi N, Shibata M, Niwa F, Kawai M, Konishi Y, et al. Effects of preterm birth on intrinsic fluctuations in neonatal cerebral activity examined using optical imaging. PloS One. 2013;8(6):e67432.

2. Lawn JE, Kinney MV, Belizan JM, Mason EM, McDougall L, Larson J, et al. Born too soon: accelerating actions for prevention and care of 15 million newborns born too soon. Reprod Health. 2013;10 Suppl 1:S6.

3. Mackay CA, Ballot DE, Cooper PA. Growth of a cohort of very low birth weight infants in Johannesburg, South Africa. BMC Pediatr. 2011;11:50.

4. Lopes BM, Duarte HF. Análise do desempenho motor em crianças prematuras: comparativos com padrão de normalidade. Rev Saude e Pesquisa. 2011;4(3):329-34.

5. Perez-Pereira M, Fernandez P, Gómez-Taibo M, Gonzalez L, Trisac JL, Casares J, etal. Neurobehavioral development of preterm and full term children: biomedical and environmental influences. Early Hum Dev. 2013;89(6):401-9.

6. Defilipo EC. Oportunidades do ambiente domiciliar e fatores associados para o desenvolvimento motor entre três e 18 meses de idade [master's thesis]. Juiz de Fora (Brazil): Universidade Federal de Juiz de Fora; 2011. Portuguese.

7. Mancini MC, Megale L, Brandão MB, Melo APP, Sampaio RF. Efeito moderador do risco social na relação entre risco biológico e desempenho funcional infantil. Rev Bras Saude Mater Infant. 2004;4(1):25-34.
8. Santos DC, Tolocka RE, Carvalho J, Heringer LR, Almeida CM, Miquelote AF. Gross motor performance and its association with neonatal and familial factors and day care exposure among children up to three years old. Rev Bras Fisioter. 2009;13(2):173-9.

9. Rodrigues L, Gabbard C. O AHEMD. Instrumento para avaliação das oportunidades de estimulação motora de crianças entre os 18 e os 42 meses de idade. Anais do $2^{\circ}$ Congresso Internacional de Aprendizagem na Educação de Infância. Porto (Portugal): Escola Superior de Educação de Paula Frassinetti; 2007. Portuguese.

10. Lemos RA, Frônio JS, Ribeiro LC, Demarchi RS, Silva J, Neves LAT. Functional performance according to gestational age and Birth weight of preschool children born premature or with low weight. J Hum Growth Dev. 2012;22(1):17-26.

11. Pilz EML, Schermann LB. Determinantes biológicos e ambientais no desenvolvimento neuropsicomotor em uma amostra de crianças de Canoas/RS. Cienc Saude Colet. 2007;12(1):181-90.

12. Maria-Mengel MRS, Linhares MBM. Fatores de Risco para Problemas de Desenvolvimento Infantil. Rev LatinoAm Enferm. 2007;15(spe):837-42.

13. Rossetti-Ferreira MC, Amorim KS, Vitória T. A Creche enquanto Contexto Possivel de Desenvolvimento da Criança Pequena. Rev Bras Crescimento Desenvolv Hum. 1994;4(2):35-40.

14. Sabatés AL, Mendes LCO. Perfil do Crescimento e Desenvolvimento de Crianças entre 12 e 36 meses de Idade que frequentam uma creche municipal da Cidade de Guarulhos. Cienc Cuid Saude. 2007;6(2):164-70.

15. Schoeps DO. Crescimento e estado nutricional de préescolares de creches filantrópicas de Santo André: transição epidemiológica nutricional no município [master's thesis]. São Paulo: Universidade de São Paulo; 2005. Portuguese.

16. Pinheiro RC, Martinez CMS, Pamplin RCO. Suporte Informativo para Educadores de Creche: Risco e Proteção nos primeiros anos de vida. Cad Ter Ocup UFSCar (Impr.). 2010;18(2):129-38.

17. Baltieri L, Santos DCC, Gibim NC, Souza CT, Batistela AC, Tolocka RE. Desempenho motor de lactentes frequentadores de berçários em creches públicas. Rev Paul Pediatr. 2010; 28(3):283-9. 
18. Almeida CS. Intervenção Motora: Efeitos no Comportamento do Bebê no Terceiro Trimestre de Vida em Creches de Porto Alegre [master's thesis]. Porto Alegre (Brazil): Universidade Federal do Rio Grande do Sul; 2004. Portuguese.

19. Eickmann SH, Maciel AMS, Lira PIC, Lima MC. Fatores associados ao desenvolvimento mental e motor de crianças de quatro creches públicas de Recife, Brasil. Rev Paul Pediatr. 2009;27(3):282-8.

20. Anzanello J. Oportunidades de estimulação, desenvolvimento motor e desenvolvimento social em crianças no primeiro ano de vida em diferentes contextos [master's thesis]. Porto Alegre (Brazil): Universidade Federal do Rio Grande do Sul; 2010. Portuguese.

21. Barros KMFT, Fragoso AGC, Oliveira ALB, Cabral Filho JE, Castro RM. Do Environmental Influences Alter Motor Abilities Acquisition? A comparison among children from day-care centers and private schools. Arq Neuropsiquiatr. 2003;61(2A):170-5.

22. Palisano R, Rosenbaum P, Walter S, Russell D, Wood E, Galuppi B. Development and reliability of a system to classify gross motor function in children with cerebral palsy. Dev Med Child Neurol. 1997;39(4):214-223.

23. Instituto Politécnico Viana do Castelo (Viana do Castelo, Portugal) and Texas A\&M University (College Station, TX, USA). Projecto AHEMD. Oportunidades de estimulação motora na casa familiar [cited 2013 Feb 13]. Available from: http://tinyurl.com/zsegzz3. Portuguese.

24. Gabbard C, Caçola P, Rodrigues LP. A New Inventory for Assessing Affordances in the Home Environment for Motor Development (AHEMD- SR). Early Childhood Educ J. 2008;36:5-9.

25. Mancini MC. Inventário de Avaliação Pediátrica de Incapacidade (PEDI): manual da versão brasileira adaptada. Belo Horizonte: Editora UFMG, 2005. 208 p.

26. Associação Brasileira de Empresas de Pesquisa (ABEP). Critério de Classificação Econômica Brasil. 2010 [cited 2013 Feb 11]. Available from: http:www.abep.org.

27. Fraga DA, Linhares MBM, Carvalho AEV, Martinez FE. Desenvolvimento de bebês prematuros relacionado a variáveis neonatais e maternas. Psicol Estud. 2008;13(2):335-44.
28. Lemos RA, Frônio JS, Ribeiro LC, Demarchi RS, Silva J, Neves LAT. Estudo da Prevalência de Morbidades e Complicações Neonatais Segundo o Peso ao Nascimento e a Idade Gestacional em Lactentes de um Serviço de Follow-Up. Rev APS. 2010;13(3):277-90.

29. Silva J, Frônio JS, Lemos RA, Ribeiro LC, Aguiar TS, Silva DT, et al. Pacing opportunities at home and skill of children with potential changes in functional development. J Hum Growth Dev. 2015;25(1):19-26.

30. Nobre FSS, Costa CLA, Oliveira DL, Cabral DAC, Nobre GCN, Caçola P. Análise das oportunidades para o desenvolvimento motor (affordances) em ambientes domésticos no Ceará - Brasil. Rev Bras Crescimento Desenvolv Hum. 2009;19(1):9-18.

31. Schobert L. O desenvolvimento motor de bebês em creches: um olhar sobre diferentes contextos [master's thesis]. Porto Alegre (Brazil): Universidade Federal do Rio Grande do Sul; 2008. Portuguese.

32. Pilatti I, Hass T, Sachetti A, Fontana C, Oliveira SG, Schiavinato JCC. Oportunidades para o Desenvolvimento Motor Infantil em Ambientes Domésticos. Rev Bras Cienc Saude. 2011;9(27):22-7.

33. Zajonz R, Müller AB, Valentini NC. A influência de fatores ambientais no desempenho motor e social de crianças da periferia de Porto Alegre Maringá. J Phys Educ (R da Educacao Fisica/UEM). 2008;19(2):159-71.

Received in 09/24/2014

Recebido em 24/09/2014

Approved in 04/18/2016

Aprovado em 18/04/2016 
